\title{
NEGLECTED FUNDAMENTALS OF PRIZE LAW
}

\author{
Thomas Baty \\ of the Inner Temple, Barrister-at-Law
}

While a prolonged period of peace has multitudinous advantages, it has nevertheless one little defect. It obliterates all knowledge of prize law, and especially all knowledge of prize procedure. It is not credible that any lawyer or any merchant who had lived through the Napoleonic period would have accepted such a list of contraband as seems now to be considered normal; or would have seen nothing strange in the suggestion that contraband was whatever a belligerent saw fit to declare such. Nor would the men who had heard Sir William Scott proclaim that the principles of blockade were not to be subverted because in some particular case they would detract from a blockade's efficiency, ${ }^{1}$ feel apprehensive that they would be subverted because of the introduction of railways. The neutral merchant who heard of the Imina Baumann ${ }^{2}$ knew that the sovereign rights of the neutral port were superior to the momentary exigencies of the hardestpressed belligerent state.

But Peace comes, and we forget. Sixty years after the Imina Baumann ${ }^{3}$ Chief Justice Chase unlocked the floodgates of belligerent pretensions, and did away with the security of the neutral port. Not on any calculated desire to restore the balance disturbed by railways, be it noted, for railways were scarcely in question, but simply on grounds of belligerent advantage. A hundred years after the French admiral Allemand stayed his destructive hand when he met neutral American and Swedish merchantmen, the neutral flag was sent to the bottom in the East by the Russian and in the West by the German. We very easily forget.

And it is very easy to forget procedure. It is the peculiar preserve of a few-a very few-lawyers and court officials, mostly of advanced years. Sailors and officers may know something of it, but the public knows nothing and cares less. By the time of the next war a new generation of lawyers has arisen, whose knowledge and interest is precisely that of the public. Text-books deal mainly with substantive law. Procedure has to be disinterred from musty books. And very

${ }^{1}$ The Ocean (1801) 3 C. Rob. 297; The Luna (1810) Edw. Adm. I90; The Stert (180r) 4 C. Rob. 65.

${ }_{3}$ C. Rob. I67.

'This case is usually, and apparently improperly, cited as The Imina. The inaster's name was Vroom (see Contents of 3 C. Rob.), and Baumann was seemingly part of the ship's name. This kind of mistake is often made; thus Rothery,

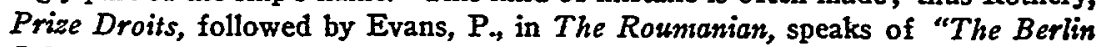
Johannes"-really The Berlin, Johannes Poort, master. 
often these neglect the obvious. Fundamental rules are assumed to be too well known to need express statement.

Some such fundamental rules of prize, law have been completely forgotten in the course of recent discussions, the learned and honorable disputants having apparently no inkling of the fact of their existence. They fail to appreciate the fact that the forcible seizure of a vessel under a friendly flag is and ever was an extremely serious thing, and they regard it with much the same leniency as an arrest by a policeman - a thing to be scrutinized certainly, but not a thing intolerable except when unjustified on the clearest grounds. The honor of the flag, a thing for which the Chesapeake's men died, has become to them a name. They have forgotten the fundamentals of prize law: those principles which secured the freedom of the neutral flag from invasion when hoisted on a ship of its nationality.

Ships were never "searched" at sea. If there is one thing of which the sciolist is more convinced than another, it is that "in the old days" the "small ship" of the period was regularly searched, in the sense of her cargo's being "rummaged," at sea. It is a complete fallacy. Ships never were so rummaged or searched as a preliminary to detention. The first principle of prize law, American, French, and English alike, was the imperative command-" $A$ captor shall not break bulk." And without breaking bulk how is rummaging possible?

The cause of the mistake is a careless misinterpretation of the word "search." With their minds full of municipal law and the searches effected by custom house officers and police constables, modern publicists have rashly concluded that the search implied in the expression "visit and search," meant a general overhauling of the cargo. It did not.

The modern ship, the sciolist thinks, is too big to be properly rummaged at sea. So she must be brought into port and rummaged, before any liability for detaining her arises or can arise. On the contrary, she is in scarcely the same situation as the old small vessels. The boarding officer must make up his mind without tampering with the cargo whether he is going to make a case of it or not. There is no more difficulty in looking over a liner's papers than a schooner's. If, and only if, they raise a case for inquiry, is the officer entitled to bring the vessel into port and ask the court to look at the cargo.

"Before the captain of the Nonsuch left the Anna Maria, in pursuit of other objects, he ought to have decided either to seize her as prize or to restore her." 4

'The Anna Maria (1817) 2 Wheat. 327, 334. In this case Marshall remarks obiter that a captain is entitled to do all that is necessary, and no more than is necessary, to enable him to establish the vessel's character and voyage. This statement must be completed by adding the words, "by the proper and legal evidence." In the case before him, the captors had made a violent search of two hours' duration for papers, breaking open trunks and the like, but without, so far as appears, laying a finger upon the cargo. Their violence and other misconduct resulted in a decree being made against them for damages. 
Before one barrel can be broached, the responsibility must be taken and the risk run of instituting legal proceedings. It is no gallant captain, but the officer of the court, acting under a judicial commission as a step in the legal process, who effects the physical search. The proceeding, technically known as a "commission of unlivery," forms with the return to it part of the material in the cause.

Sir John Marriott, in the pamphlet to which reference will presently be made, refers to another possibility, which he does not particularizesearch "in certain special cases in the presence of public officials." What he alludes to is uncertain, but certainly not a search at sea :-

"Although there was the strongest reason to think that by unloading there might be found the real ship's papers of the Henrick \& Alide, and more contraband in boxes and barrels, not set down in the bills of lading and papers produced, yet Lord Mulgrave's ${ }^{6}$ counsel did not advise him to search the vessel to the keel. That can only be done in special cases, in the presence of public officials, and in others by an express decree of the judge, who is bound to hear both sides on the point."

This passage, written by an eminent prize judge, is consistent with all the cases, all the contemporaneous text-books, and all the facts of history. Again and again in Lord Stowell's decisions do we find absolute injunctions against "breaking bulk"; and evidently it was considered as a gross piece of presumption on the part of officers, and one likely to lead to all kinds of abuse. In particular, it deprived the court of that thorough control over the proceedings which it was always careful to assert. ${ }^{8}$ Even to land cargo was -objectionable.

"He landed the bullion,--if this had been done in the ordinary course of prize, and whilst any cause was depending on it, it would have been a great irregularity."

Much less was breaking bulk permitted. Captors might play all sorts of tricks with the cargo if it were allowed. ${ }^{10}$

'Mémoire justificatif de la conduite de la Grande Brétagne en arrêtant les navires étrangers et les munitions de guerre destinées aux insurgens de l'Amérique. Londres, I779. See note 22 infra.

'The captor.

'The L'Eole (I805) 6 C."Rob. 220, 225; The Washington (I806) id. 275, 280;

The Concordia (1799) 2 C. Rob. I02.

${ }^{8}$ Note that to search for papers was not so much objected to if it could be done without disturbing cargo. The Atalanta (1808) 6 C. Rob. 440. Cf. The Anna Maria, note 4, supra.

- The Princessa (I799) 2 C. Rob. 31, 39.

${ }^{10}$ We may add to the cases in note 7 from C. Rob. The San Joan Baptista Inner Tempie folio records of Prize Appeals (formerly Dr. Lushington's) Vol. 1800-1805, fo. 453, where the Euphrosyme had taken specie and jewels out of the captured ship, and taken them to the Cape, where they were condemned. The Lords restored them with costs. 
A typical case is The Washington, ${ }^{11}$ where Sir W. Scott, insisting that "bulk shall not be broken," refused to consider that a proper and convenient port to which to carry a prize, where the vessel could not enter without unloading.

"If there is not depth of water to allow [the] vessel to lie without taking out the cargo, 'non erit his locus'; since captors are not to meddle with the cargo in any manner, without the authority of the court, which cannot be exercised until the vessel has been brought into port."12

Ortolan ${ }^{13}$ defines the "droit de visite," which he identifies with the English "right of visit and search," as "le droit de monter à bord, d'exiger l'exhibition des papiers en usage, et d'y procéder á un examen plus ou moins minitieux." The exercise of the right, he points out, is an act neither of authority nor of jurisdiction. Heffter ${ }^{14}$ says that the last formality of "visit" is the inspection of the ship's papers. There is, indeed, a current of purely theoretical opinion running from Vattel to Ortolan and Calvo, which makes the impractical concession of allowing captors to rummage if there are circumstances of great suspicion. This indulgence to the suspicions which captors will never be slow to entertain is unknown alike to English doctrine and to immemorial practise.

Nor, it is believed, is there in fact a single case in the reports of the classical period, where search in the sense of rummaging is reported as revealing an impeachable cargo, or one not corresponding with the bills of lading.

The recent practise of bringing a ship in, and then making up one's mind whether to proceed or not, was attempted in Sir W. Scott's day in The Wilhelmsberg. ${ }^{15}$ It was not carried to the extreme of omitting to commence prize proceedings until the captors had satisfied themselves, but it took the form of commencing proceedings, and attempting to repudiate responsibility for the detention by offering to release unconditionally when it became clear that process would be unsuccessful. As Scott put it,

"To release a vessel in this summary manner without her consent, after she was once brought in, would be contrary to the directions of the Prize Act."

\footnotetext{
II Supra, note 7, at p. 277; see also p. 280.

${ }^{12}$ In the same case, Sir W. Scott expressed a strong opinion that Shetland or S. Kilder would not be "convenient ports" when proceedings were to take place in London. Jersey was allowed in the case of Jersey privateers. Cf. The Williamsberg (1804) 5 C. Rob. 143 (Shetland).

${ }^{23} 2$ Régles internationales et diplomatie de la mer (1856) 250.

"Das europaische völkerrecht (I888) sec. I69.

is Supra, note 12, at p. I44
} 
The real reason why ships to-day are brought in and not rummaged at sea is not for greater convenience in rummaging, because they cannot be, and never were, rummaged until formally charged and the risk of costs incurred. It is for the better collection of evidence (including its collection by unauthorized and improper rummaging); vulgarly, for the getting up of a case.

In the old days a case was never "got up" against a ship or goods, for the simple reason that the cause had to be tried on certain fixed evidence. That consisted in (I) every particle of written matter to be found on the ship, and (2) the answers of selected members of the ship's company to certain set interrogatories. The only thing resembling the "getting up of a case," was the getting at these standard witnesses.

This brings us to our second head.

Captor's evidence was never allowed. It is equally clear on the authorities that captors were never listened to. Nothing is more puzzling to the modern lawyer, but nothing is more certain. As has been said by Wheaton, Story, Twiss, and Phillimore, it is a great mistake to import into the administration of prize law the methods and doctrines of the common law. In fact, Story says that " no proceedings can be more unlike."16 A prize cause is not a contest between two equally matched parties, contending about some cause of quarrel. It is a process by which an officer of one state claims to seize and confiscate from under a friendly flag, the property of citizens of another. He is required, therefore, to prove his case up to the hilt. He is not allowed to adduce evidence of his own; he must prove his case by the admissions of the other side. It is not in the least like the theory of an action at law. It is not even like the theory of a criminal prosecution. We have not, in a prize case, a tournament between two contending suitors, an attack which must be parried if sufficiently damning. We have an extraordinary and most delicate claim which no amount of evidence can support, if it is not the admission of the party attacked. And this is always forgotten to-day.

As the writer observed in I9I0, 17

"Sir Travers Twiss wrote, some forty years ago, in the Law Maga$z^{2} e^{18}$ an article which remains a classical authority on the nature of

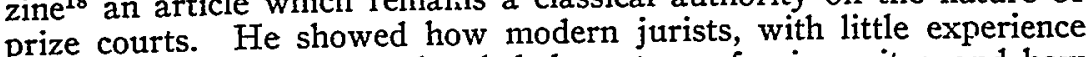
of maritime war, misapprehended the nature of prize suits; and how

${ }^{36}$ Citing (2) Halleck, International Law (3d ed. I893) ch. 32, sec. 20.

${ }^{17}$ The Inadequacy of Litigation as a Protection against Cruisers, in the Report of IoIo, Conference of the International Law Association. London, I9II.

${ }_{13}$ ( 1877 ) 3 Law Magazine and Review, I. Cf. Evarts. Brief in the Springbok Case, reprinted in the present writer's Prize Law of Continuous Voyage (London, I915). 
mistaken they were in taking it for granted that the ordinary principles of municipal evidence and procedure were naturally applicable to them. On the contrary, the admission of proof and counter-proof, with success awarded to the strongest case, is totally foreign to prize cases. The ship must be brought, by her own showing, within certain plain rules; and then she is condemned, unless, as a matter of grace, 'further proof' is allowed her to excuse herself."

This doctrine of judgment on admissions is again clear on the authorities. The celebrated Memorandum of Lee, Paul, Ryder, and Murray, ${ }^{19}$ states shortly and plainly:-

"The evidence to acquit or condemn, with or without costs and damages, must in the first instance come merely from the ship taken, viz: the papers on board and the examination on oath of the master and other principal officers; for which purpose there are officers of the Admiralty in all the considerable seaports of every maritime power ${ }^{20}$ at war to examine the captains and other principal officers of every ship brought in as prize, upon general and impartial interrogatories.21 If there do not appear from thence ground to condemn as enemy's property or contraband goods going to the enemy, there must be an acquittal: 'unless from the aforesaid evidence the property shall appear so doubtful, that it is reasonable to go into further proof thereof."

The Memorandum, which was afterwards communicated by Sir W. Scott and Sir J. Nicholl to the United States Courts through Mr. Jay, and forms the basis of American, as of British, prize law, goes on to show that where there is doubt on the primary evidence, the claimants may as a favor, be allowed to adduce "further proof"; and of course the captors may be admitted to contradict this. The case then assumes the aspect of an ordinary trial, but an indispensable preliminary to such an event is something wrong with the primary evidence-some deficiency or discrepancy in the papers or the statements of the crew.

The Lee-Murray Memorandum was prepared in I753. In I779 Sir J. Marriott composed a Memoire justificatif. ${ }^{22}$ He states the same rule as in full force.

"Ex ore tuo te judicabo. Dans le cas de lHendric et Alide, Milord Mulgrave ayant trouvé à bord des pavillons anglois, demandait au maitre d'où venoient ces pavillons, et pourquoi il les avoit. Klok répondit que ces pavillons étoit dans le dit vaisseau lorsque lis: propriétaires en firent l'acquisition. Nous n'avons cependant pas permis l'examen personnel de milord Mulgrave. Le témoignage des capteurs n'est admis dans ces procédures que dans les singulières,

${ }^{10}$ (1753). Reprinted ibid. Lee was Judge of the Prize Court, Paul, Ryder, and Murray (afterwards Lord Mansfield) were Advocate-General, Attorney-Generał, and Solicitor-General respectively.

$\approx$ Note these three words.

${ }^{21}$ Printed in I C. Rob. 38r.

$=2$ See note 5, supro. 
tels que seroient le défaut de témoignage de la perte de l'équipage du vaisseau saisi, leur fuite, ou le refus obstiné de subir un examen légal. Les articles 3, 4, 5 de l'ordonnance de la marine française, I68I, portent le même exception.

"Si les saisis confessent que le navire appertient aux ennemis, l'affaire est décidée. Mais s'ils laissent entrevoir des prévarications ou qu'ils se contredisent-si le témoignage des papiers est en opposition aux témoignages vendus de vive voix; si les documens ont été spoliés, submergés, brûlés, déchirés, ou detruits de quelque manière que ce soit; si ces documens ne sont pas parfaitement clairs, ou portent l'empreinte de l'équivoque que l'on ne doit pas attendre d'un voyage de bonne foi-voilà des soupçons graves; et ces défauts prenant leur source originelle dans le réclamateur même, négligeant ou prévaricateur, sont plus que suffisants en justice, pour qu'il soit condamné aux frais de procédure qu'il à occasionnés, quand meme on lui vendroit le vaisseau et sa cargaison.

"Ces procédures s'accordent sans doute avec celles de le cour d'amirauté de leurs Hautes Puissances ${ }^{23}$. . ."

Again,

"Les capteurs qui ne seroient pas justifiés, par le témoignage même des saisis, seroient condamnés aux frais et aux dédommagements, et même à des punitions graves."

Sir W. Scott acted on the same principles twenty years later, and so did Dr. Lushington half a century afterwards. Scott remarks that the rule

"is the very essence of prize law: it is a great mistake to admit the common-law notions in respect to evidence, to prevail in proceedings which have no analogy to those at common law. . . . It is of the last importance to preserve the most rigid exactness as to the admission of evidence."

And in The Haabet he adds,

"The general rule of law . . . is, that, on all points, the evidence of the claimants alone shall be received in the first instance; and if no doubt arises on that view of the case, the court is bound ... to take those points as fully demonstrated. . - . If I should accede to this demand, the consequence would be that I must do it upon a uniform principle of admitting affidavits universally and in all cases, though there should be nothing to excite suspicion in the original evidence, and though the language of all the witnesses is as precise as possible. I can come to no such conclusion. . . . For how could the court decide? Counter affidavits must be introduced, which would necessarily be contradictory. Which should the court believe? Can it be maintained that preference should be given to the captors, and that in opposition to the general rule of law which has given the preference the other way, and which directs that the property of the neutral claimant shall not be condemned except on evidence coming out of his own mouth, or arising out of the clear circumstances of

\footnotetext{
20 Néerlandaises.
} 
the transaction? If this rule is unsatisfactory to captors, it is nevertheless the rule which the law prescribes. It is my duty to take care that the rules of law are observed, and that the rights of war are not exceeded; and certainly in no cases more than in this particular branch of the law of nations, which must in its nature operate with severe restraint upon neutral commerce."24

Story remarks on the irregularity of admitting extraneous evidence, ${ }^{25}$ and Lushington cogently observes,

"The admission would occasion delay, expense, and doubt. There is always difficulty in deciding between conflicting affidavits. How enormously would that difficulty be enhanced when the affidavits come from persons all interested in the result, and for the most part prepared abroad, and from translations also!"

French practise was perfectly conformable, ${ }^{28}$ and so was Dutch. ${ }^{27}$

In short, the captor brings the merchant's property to the country, but it would be going too far to force him to come himself as well with a cloud of witnesses to defend it. The essence of prize proceedings is simplicity. The introduction of complicated cross-evidence is foreign to it. It is contrary to mercantile security and national honor to admit such evidence, and to enable every belligerent cruiser to force neutrals to an expensive trial. In The Sarah ${ }^{28}$ Scott remarked,

"The practise of the court would be led away from the simplicity of prize proceedings, and there would be no end to the accumulation of proof that would be introduced in order to support arbitrary suggestions."

Simplicity was not desired for its sweet sake alone, but because neutrals would not in the long run stand being driven to sustain their rights against cruisers by the long and expensive process of witness trials as though they were subject to the belligerent's ordering jurisdiction. His right was extraordinary, and it was not to be enforced by the ordinary means which he would invoke as against his own subjects.

The system elaborated in the I7th and I8th centuries, and thus expounded, proceeded on the view that ships were, in the energetic language which prevailed at that time and which has been held in more recent days by so great authorities as Daniel Webster, Lord

\footnotetext{
${ }^{24}$ Giertsen, master (1805) 6 C. Rob. 54, 55, 57 ff.

${ }^{25}$ The Dos Hamanos (1817) 2 Wheat. 8I.

"Ordonnance de la Marine (I68I) Art 24, 25, and passim.

${ }^{27}$ Cf. The Hurtige Hane (1801) 3 C. Rob. 324, 326, note. "Les vaisseaux et marchandises neutres seront ausi confisquez, quand it constera par les lettres de cargaison, ... ou autres documens, qu'ils ont ete chargez dans les ports de Flandres, ou qu'ils sont destinez d'y aller. . ." (Resolutions of the StatesGeneral regarding blockade, June 26,1630 ).

${ }^{28}$ (I8OI) 3 C. Rob. 330, 33I.
} 
Chancellor Lyndhurst, and Count Cavour, ${ }^{28}$ "territory," and that a forcible interference with ships or goods under the protection of the national flag was not a mere matter for trial, but was required to proceed on the plainest and most obvious principles of justice.

We seem to have moved far from that position now. The sinking of the American ship W.P. Frye by the Germans in I9I 5 was received with much more philosophic calm than the removal of two gentlemen from the Trent was in I862. The removal of military Turks from the British ship Africa by Italians in I9II was received with no emotion at all; in fact, nobody noticed it. The inviolability of the national flag has passed from the public consciousness. The sanctity and independence of national vessels and their freedom in principle from all foreign interference seems entirely to have slipped into oblivion. Ortolan's eloquent panegyric on the spirit which animates a ship's company from captain to cabin-boy and presents it to the stranger as a united, impenetrable whole, is pathetically out of date. Perhaps it is because we have come to look at a ship as a mere moneymaking implement; perhaps because the perils of the sea are fewer than in the days of pirate and cockle-shell.

Or perhaps-dare it be hinted?-because cosmopolitanism has sapped the foundations of national pride. One is not certain in spite of the great demonstrations of willingness to incur every sacrifice in order to make the world safe, that this is not the correct explanation.

Anyhow we no longer seem to think that the forcible capture and confiscation of our ships touches us very closely. It seems to be thought a matter which may well be left to the tedious and harassing processes of the common law. But after all a great deal more than national sentiment is concerned.

It is seldom indeed-Professor Montague Bemard thought it hardly ever happened-that an owner whose ship or goods are detained receives anything like fair indemnity. Costs and damages are seldom awarded, and if awarded are nothing like adequate to reimburse the claimant for his trouble and anxiety, not to speak of out-of-pocket expenses. Under the irregular and improper new practise of detaining before proceedings are commenced in the hope of discovering evidence by irregular rummaging and the usual detective methods, there seems no possibility of obtaining costs and damages at all: first, because there is no process wherein to prove for their allowance, and secondly, because in most if not all cases the detention would be regarded as justified. If we once grant that a case is to be tried on all kinds of extraneous suspicions, we must concede that there are few cases in which suspicions might not fairly be alleged. Mental security vanishes; every neutral ship may be forced to justify herself at her own expense.

\footnotetext{
- See Lawrence, Visit and Search, 182; 48 British State Papers, 428 ("The Cagliari, on the high seas, was a fragment of Piedmontese territory").
} 
As we have seen, the claimant is at a disadvantage. He is more or less at the mercy of the court. ${ }^{30}$ He lives far away; his language and ideas may be entirely alien; he will certainly incur heavy costs and delays if he is forced to a common-law trial. The Memorandum provides a fair and just substitute; let him be judged out of his own mouth. Say its authors with all the weight of their unrivalled experience,

"In this method all captains at sea were tried during the last war, by Great Britain, France, and Spain, and submitted to by the neutral powers. In this method, by courts of admiralty acting according to the law of nations and particular treaties all captains at sea have immemorially been judged of in every country of Europe. Any other method of trial would be manifestly unjust, absurd, and impracticable."

Yet our modern luminaries have not hesitated to adventure to practise strange methods. By Rule I5(2) of the Prize Court Rules made in I9I4 under statutory authority, but not with the advantage of legislative discussion,

"a cause for the condemnation of a ship [or goods ${ }^{31}$ ] other than a ship [or goods] of war shall be heard upon the following evidence:

". . (d) the evidence given at the hearing, of any witnesses, whether on behalf of the captors or of any other party.

"(e) such further evidence, if any, as may be admitted by the Judge."

This is to assimilate the practise completely and formally to that of a common-law trial. Discovery, that process which, as Lord Justice Smith once said, has "made law to stink in the nostrils of business men," is introduced wholesale by rules 9(I-7). Claimants have been driven to give security for costs like any foreign plaintiff in an ordinary suit; and it is believed that Evans, P., required neutrals to give security for $\sum_{150}$ before they could be admitted to claim their own property. We compare unfavorably with $\mathrm{r} 799$, when Scott finely said,

"It is not a thing becoming the justice of this country that the subjects of other states should be put to inconvenience about the recovery of their property . . . to answer purposes of British convenience." ${ }^{\prime 32}$

In short, prize law doctrines have been completely submerged.

This was very natural; common lawyers cannot be expected to appreciate the fact that there are other methods of trial differing toto caelo from their own. But it is none the less unfortunate.

${ }^{\circ} \mathrm{Cf}$. the writer's Britain and Sea Law, 62.

"By a preposterous interpretation clause [I(2)] "ship" includes "goods" and "freight."

"The Concordia (1799) 2 C. Rob. 102, 103. 
The whole theory of the new and revolutionary practise is in accord with the tendency to further the interests of the belligerents. The conception of continuous voyage requires captors' evidence to make it effective. The pathetic plea of belligerents, that railways have turned the ports of neutrals into ports of the enemy (forgetting that steam cruisers have enormously increased the difficulties of contrabandists and blockade-runners), is met at once by a melting concession of liberty to suppress the trade of all neutral ports. The wail that a country cannot now be hermetically sealed (a wail which ignores or forgets the fact that it never could be) is met by an indulgence to be a universal nuisance. The desire to force merchants to the delays, difficulties, and expense of contested trials is met by a bland "Nothing more proper! How else can a case be tried?"

These concessions would never be made if a weak belligerent were in question. It is perfectly certain that great maritime countries will not in future submit to have their ports and commerce held up by a minor power. ${ }^{33}$ So that we have the very regrettable conclusion that the law is what the strong choose to make it. The only escape is to regard the complaisance of neutrals in the late struggle as their way of giving limited assistance to the forces of right and justice. Thus regarded, the encroachments on neutral rights would be exceptional, and like the fulminations of Napoleon and the British Cabinet in 1806, they would fail to serve as precedents for the future.

As Puffendorf put it at an earlier day, ${ }^{34}$

"Those princes wisely judge that it would not become them to take precipitate measures, whilst other nations are combining their whole force to reduce within bounds an insolent and exorbitant power which threatens Europe with slavery."

The words of Sir W. Scott are entirely applicable:

"The nature of the present war does give this country the rights of war, relatively to neutral states, in as large a measure as they have been regularly and legally exercised at any period of modern and civilized times. I leave it to the judgment of Europe whether I estimate the nature of the war justly, when I declare that I consider this as a war in which neutral states themselves have an interest much more direct and substantial than they have in the ordinary, limited, and private quarrels . . . of Great Britain and its great public enemy."

Such considerations cannot alter the rights of neutrals, however they may affect their complaisance.

Because railways have facilitated transit-and railways are expensive and easily congested-it is absurd to invest belligerents with a

\footnotetext{
* See Van Houten's observations in (IgI7) 3 Recueil des Rapports, 59 (Organization pour une Paix Durable, La Haye).

"Cited in The Maria (1799) I C. Rob. 340, 352.
} 
universal inquisitorial power, as well as with fast cruisers which can catch anything.

Nothing, in fact, is so remarkable as the apathetic levity with which the facile excuse of "railways" is put forward to cover the very gravest interference with the commerce of neutral states. It is hardly denied that, rightly or wrongly, the allied maritime policy of I9r 5 amounted practically to a prohibition of neutral trade with the enemy. Was it necessary merely because of railways, to put the world back into Queen Elizabeth's days in this regard? The merest tyro in affairs would suppose that before such a momentous decision was taken, the true effect of railway facilities would be carefully investigated, and some attempt made to estimate the effect of the increased facilities upon blockade. Yet not the slightest detailed attempt was made; the world shot blindfold into anarchy dispensed from "juridical nicetiẹs."

Even had the effect been ascertained to be considerable, it may be doubted whether the necessary outcome would have been to invest belligerents with fresh powers. A very substantial offset in their favor is afforded by the modern fast cruiser, which is incomparably more effective against the freighter than the frigate was against the merchantman. An eminent British judge, Lord Kingsdown, regarded it as much more than an offset. According to Halleck,

"two or three steam vessels may be as effective now as twenty sailing vessels were formerly." ${ }^{\prime 35}$

But even if the belligerents' power were impaired (the writer inclines to think it has been, on balance, increased) it by no means follows that means must not be devised to restore it. Some countries were always difficult to blockade in comparison with others; there was never any idea of adding an additional handicap to equalize matters! If a country was an awkward one to blockade, or became such, that was its luck and the would-be blockader's misfortune. Law is not designed to correct the defects of geography. And if science steps in to render blockades more difficult, it might well be argued that it is not the province of law to correct the indiscretions of science.

It must always be a grave and urgent matter for a nation to find its ports rendered useless. Such a measure must always put considerable stress upon it. A country cannot, and never would, be hermetically sealed, and the mere quantum of less or more which filters into it from overland sources cannot affect the principle. Sir W. Scott said in The Stort, ${ }^{36}$

\footnotetext{
${ }^{35} 2$ International Law (Baker's ed. 1908) ch. 25, sec. 7. Cf. also Preface to Prize Law and Contimuous Voyage, supra, note 18.

* (I801) 4 C. Rob. 65, 67.
} 
"The commerce, though partially open, is still subject to a pressure of difficulties and inconvenience. To cut off the power of immediate export and importation from the ports of Holland is of itself no insignificant operation."

The law of blockade cannot be altered because certain blockades have become difficult. Had blockade, for some reason, become everywhere or generally inefficacious, it would be time to discuss the provision of a working substitute. But as long as the closure of ports drives a belligerent to fall back on congested and enormously expensive railroad transit, it cannot be dismissed as a measure devoid of menace. At the very least, the basic facts ought to be examined before dismissing "juridical" considerations to Saturn.

Sir W. Scott's felicitous language may again be adopted, ${ }^{37}$

"I am not ignorant that amongst the loose doctrines which modern fancy, under the various denominations of philosophy and philanthropy, and I know not what, has thrown upon the world, it has been within these few years advanced, or rather insinuated, that 'changes are necessary.' Upon such unauthorized speculations it is not necessary for me to descant. The law and practise of nations . $\therefore$. give them no sort of countenance; and until that law and practise are new-modelled in such a way as may surrender the known and ancient rights of some nations to the present convenience of other nations, (which nations may perhaps remember to forget them, when they happen to be themselves [neutrals]) no reverence is due to them. - . If it were fit that such a [changed] state should be introduced, it is at least necessary that it should be introduced in an avowed and intelligible manner, and not in a way which, professing gravely to adhere to that system which has for centuries prevailed among civilized states, and urging at the same time a pretension utterly inconsistent with all its known principles, delivers over the whole matter at once to eternal controversy and conflict, at the expense of the constant hazard of the harmony of states, and of the lives and safeties of innocent individuals."

Nor is the plea that a proper and orthodox blockade is impossible in these days of submarines a valid one. It is conclusively answered by the fact that in actuality very few cargoes did penetrate the British maritime cordon. An orthodox blockade might therefore with perfect propriety have been declared of the German North Sea ports. The drawback was that it was impossible legally to blockade the Baltic ports; and in order virtually to blockade them the extraordinary system of an extended list of contraband coupled with an arrogation of power to stop it on its way to neutral ports was devised.

It is not proposed here to elaborate the criticism of this system which the present writer has elsewhere ventured, on purely academic grounds, to put forward. It is desired, however, to emphasize that it is of one texture with the bringing in of ships while a case is got up against

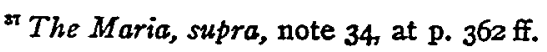


them, and with the wholesale admission of captors' evidence-which are things utterly repudiated in the past, and deserving of like reprobation in the future.

At any rate, those. who believe that neutrals in general deserve, and in the long run will obtain, more sympathy from the world than belligerents, will so conclude. That there will be neutrals and belligerents in the future as in the past, is a further proposition which it is not for us here to argue or to raise.

We had thought, since the Declaration of Paris, and as late as the year Igoo, that the trend of the world's opinion was against the belligerent and in favor of the neutral. The disquiet caused by the "continuous voyage" decisions-very few in number-was allayed by the reflection that the overwhelming current of opinion was to discourage belligerency as a nuisance to the world's highways. The Russian pretensions of I904-5 shook this complacency. The feeble manner in which neutral statesmen handled the problems presented by the Russian action greatly increased the sense of insecurity. The belligerent, though a nuisance, was seen to be allowed to have much of his own way; his pretensions were admitted to have as much weight as time-honored precedent to the contrary. The result, ${ }^{38}$ due to a long period of peace and forgetfulness, has been to reduce neutral immunities to the vanishing-point. There could be no better illustration of the cardinal maxim of politics,

"The price of our liberties is eternal vigilance."

${ }^{3} \mathrm{As}$, the present writer may be excused from observing, was predicted in a paper entitled The Recrudescence of Belligerent Pretensions, read at Christiania in 1905. 